\title{
ANALISIS KONDISI ATMOSFER TERKAIT KEJADIAN BANJIRMENGGUNAKAN DATA RADIOSONDE DAN CITRA SATELIT HIMAWARI-8 (STUDI KASUS : SUNGAILIAT, KABUPATEN BANGKA TANGGAL 12 FEBRUARI 2018)
}

\author{
Wasfi Qordowi ${ }^{1}$ \\ Sekolah Tinggi Meteorologi Klimatologi dan Geofisika \\ Jl. Perhubungan I No. 5, Pondok Betung, Pondok Aren, Pd. Betung, Tangerang Selatan, Kota \\ Tangerang Selatan, Banten 15221, Indonesia \\ Email : wasfi.qordowi@stmkg.ac.id
}

\begin{abstract}
On February 12, 2017, there was a phenomenon of heavy rain in the Sungailiat area, Bangka Regency which is located at coordinates $1^{\circ} 52^{\prime} 43.14^{\prime \prime} S$ and $106^{\circ} 6^{\prime} 57.29^{\prime \prime}$ E. Rain occurs from early morning at around 20.00 UTC or 3:00 WIB with a peak of heavy rain starting at 22.00 UTC or $05.00 \mathrm{WIB}$. The phenomenon of heavy rain caused several areas to be submerged by flooding, especially in the Sungailiat Inpres Market area, In front of the Bangka Regent office, and the fishing village. This research was conducted to measure environmental conditions when they occur. Analysis of this data uses Radiosonde air observation data on the Pangkal Pinang Meteorological Station which was processed with RAOB (The Universal RAwinsonde OBservation Program) software, and Himawari-8 Weather satellite image data processed with SATAID software then analyzed descriptively. The results show that the rain phenomenon that occurred on February 12, 2017 by the results of himawari-8 satellite image analysis is at $-75^{\circ} \mathrm{C}$ in the 22.00 to 23.00 UTC range and the above air index analysis is KI 27.5, LI - 4, 6, SI-0.3, TT 45.4 and SWEAT 205.4 is used when events are very unstable which affects the growth of convective clouds and produces bad weather.
\end{abstract}

Keywords: Himawari, Radiosonde, banjir

\begin{abstract}
Abstrak: Pada tanggal 12 Februari 2017, telah terjadi fenomena hujan lebat di wilayah Sungailiat, Kabupaten Bangka yang terletak pada koordinat $1^{\circ} 52^{\prime} 43.14 "$ LS dan $106^{\circ} 6^{\prime} 57.29 "$ BT. Hujan terjadi sejak dini hari sekitar pukul 20.00 UTC atau pukul 03.00 WIB dengan puncak hujan lebatnya terjadi mulai pukul pukul 22.00 UTC atau pukul 05.00 WIB. Fenomena hujan lebat tersebut menyebabkan beberapa wilayah di sungailiat terendam oleh banjir terutama didaerah Pasar Inpres Sungailiat, depan kantor Bupati Bangka, dan kampung nelayan. Penelitian ini dilakukan untuk meninjau kondisi fisis atmosfer saat kejadian secara analisis faktor cuaca lokal untuk mengetahui penyebab dari fenomena tersebut. Analisis dari kejadian ini menggunakan data pengamatan Radiosonde udara atas Stasiun Meteorologi Pangkal Pinang yang diolah dengan software RAOB (The Universal Rawinsonde Observation Program), dan data citra satelit cuaca Himawari-8 yang diolah dengan software SATAID kemudian dianalisa secara deskriptif. Hasil identifikasi menunjukan bahwa fenomena hujan lebat yang terjadi pada tanggal 12 Februari 2017 dipengaruhi oleh suhu puncak awan dari hasil analisa citra satelit himawari- 8 berada di angka $-75^{\circ} \mathrm{C}$ pada rentang jam 22.00 sampai 23.00 UTC dan analisa indeks udara atas yaitu KI 27.5, LI -4.6, SI -0.3, TT 45.4 dan SWEAT 205.4 mengindikasikan bahwa udara atas pada saat kejadian sangat labil yang memicu pertumbuhan awanawan konvektif dan berpotensi menghasilkan cuaca buruk.
\end{abstract}

Kata kunci: Himawari-8, Radiosonde, banjir 


\section{PENDAHULUAN}

Cuaca merupakan suatu kejadian atmosfer yang mempengaruhi kehidupan manusia, sehingga manusia akan selalu berusaha untuk menyesuaikan diri terhadap kondisi cuaca yang terjadi. Salah satu unsur cuaca yang mempengaruhi kehidupan manusia ialah curah hujan. Curah hujan yang dianggap mengganggu kehidupan manusia adalah curah hujan yang memiliki intensitas tinggi karena pada daerah tertentu dapat menimbulkan banjir.

Letak Indonesia yang berada pada $6^{\circ} \mathrm{LU}$ sampai dengan $11^{\circ} \mathrm{LS}$, serta $95^{\circ} \mathrm{BT}$ hingga $141^{\circ} \mathrm{BT}$ menjadikan banyak cuaca signifikan yang terjadi. Indonesia merupakan wilayah dengan karakteristik cuaca dan iklim yang unik. Sebagai salah satu wilayah negara di daerah tropis, Indonesia berpotensi terjadinya cuaca ekstrem seperti hujan lebat. Kejadian hujan lebat dengan curah hujan tinggi yang berasal dari proses konvektif dapat berdampak pada terjadinya banjir di beberapa wilayah di Indonesia.

Kerugian yang dihasilkan oleh bencana banjir dapat dikurangi dengan cara mengetahui gambaran secara spesifik kondisi yang menyebabkan terjadinya banjir. Salah satu faktor penyebab terjadinya banjir adalah curah hujan dengan intensitas tinggi. Kondisi curah hujan dengan intensitas tinggi dapat diketahui dengan cara melakukan analisis atmosfer pada saat terjadinya hujan dengan intensitas tinggi, sehingga kerugian yang dihasilkan oleh banjir dapat dikurangi karena sudah memiliki analisis sehingga . Banjir akan menjadi masalah jika bantaran banjir menjadi daerah terbangun dengan nilai sosial ekonomi tinggi.

Pada tanggal 12 Februari 2017, telah terjadi fenomena hujan lebat di wilayah Sungailiat, Kabupaten Bangka Hujan terjadi sejak dini hari sekitar pukul 20.00 UTC atau pukul 03.00 WIB Fenomena hujan lebat tersebut menyebabkan beberapa wilayah di sungailiat terendam banjir.

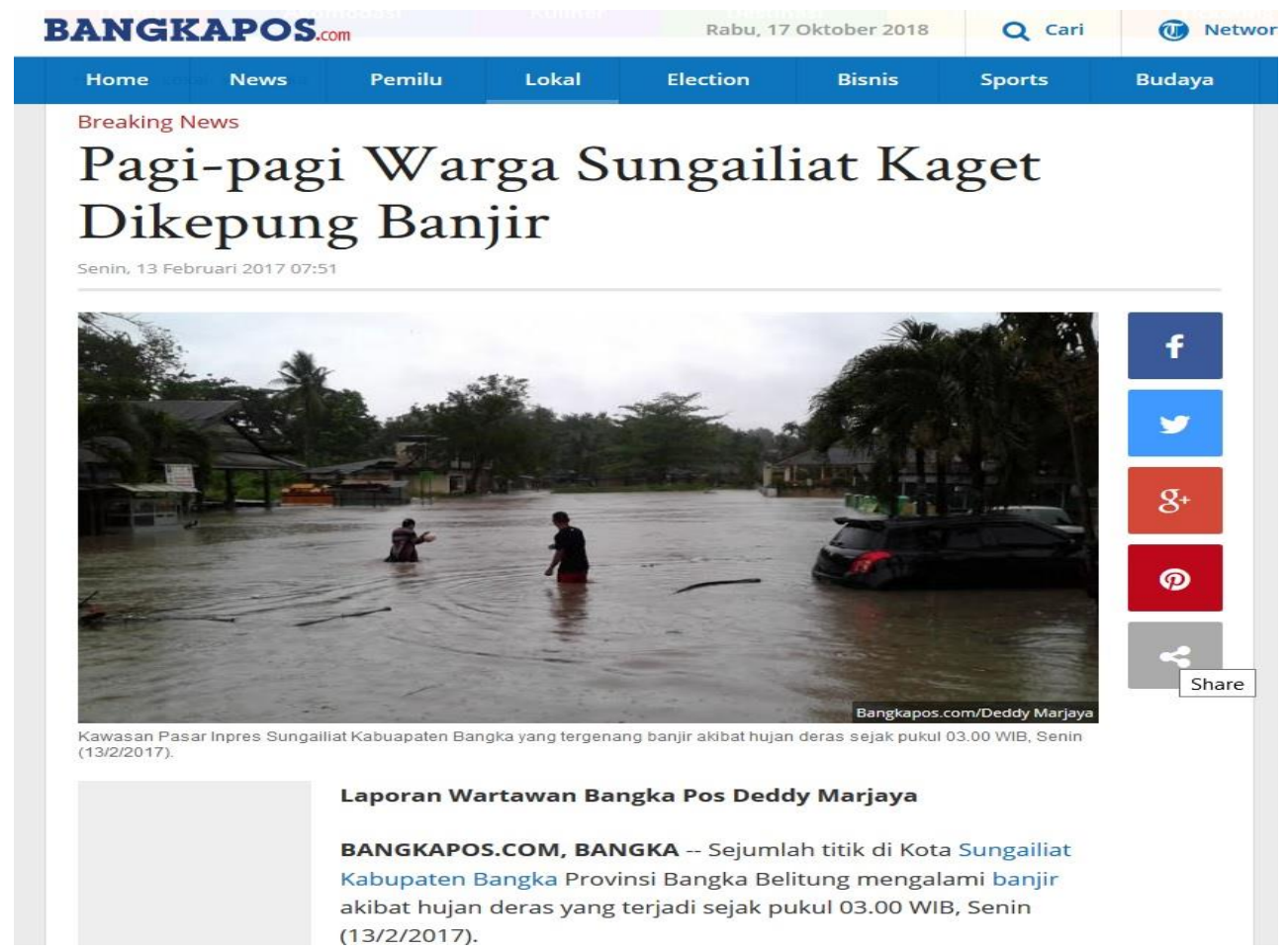

Gambar 1. Pemberitaan kejadian banjir sungailiat (www.bangkapos.com) 
Kejadian hujan lebat merupakan salah satu bentuk cuaca ekstrem di mana kondisi parameter-parameter cuaca mendukung terjadinya cuaca signifikan tersebut. Parameter tersebut berupa kondisi angin, kelembaban dan suhu, apabila parameter-parameter tersebut berada pada kondisi yang mendukung terjadinya proses konveksi yang kuat maka akan membentuk awan konvektif yang dapat membentuk hujan dengan intensitas curah hujan yang besar Untuk mengetahui parameter penting pembentukan cuaca suatu wilayah perlu dilakukan analisis cuaca atau analisis dinamika atmosfer. Tujuan utamanya adalah untuk mengetahui parameter yang dapat mempengaruhi aktivitas cuaca pada waktu kejadian bencana banjir tersebut.

Analisis dilakukan dengan menggunakan data pengamatan udara atas radiosonde yang diperoleh dari Stasiun Meteorologi Pangkal Pinang (96237) pada tanggal 12 Februari 2017 jam 12.00 UTC serta tanggal 13 Februari jam 00.00 UTC. Analisis sounding diperlukan untuk mengetahui profil suhu, kelembaban, arah dan kecepatan angin atas serta indeks-indeks konvektif, yang berguna dalam mengevaluasi atau mendiagnosa kondisi vertikal udara untuk prakiraan cuaca lokal (Winarso, 2009). Analisis kondisi atmosfer saat sebelum terjadinya hujan dengan intensitas tinggi yaitu pada 12 Februari 2017 jam 12.00 UTC dapat diketahui dengan melakukan pengamatan kondisi udara atas. Data yang dihasilkan oleh radiosonde akan dianalisis dengan menggunakan metode perangkat lunak yang dinamakan The Universal Rawinsonde Observation Programs (RAOB). Perangkat lunak ini sangat membantu dalam menganalisis dan menurunkan parameter atmosfer yang diperoleh dari data radiosonde.

Analisis cuaca skala lokal juga dilakukan dengan menggunakan citra satelit himawari 8 kanal I2 untuk mendapatkan gambaran perawanan ketika terjadinya hujan lebat. Analisis citra satelit Himawari-8 menggunakan aplikasi citra satelit yang realtime dan mudah diakses yaitu SATAID (Satellite Animation and Interactive Diagnosis). Aplikasi SATAID adalah aplikasi yang dikembangkan oleh Satellite Meteorological Center (SMC) Japan Meteorological Agency (JMA) untuk menganalisis citra satelit. Aplikasi ini dapat menampilkan gambar satelit dari data binary dan digunakan untuk belajar dan berlatih dalam mengasah kemampuan dalam menganalisis. Selain itu juga dapat digunakan dalam memantau situasi yang sebenarnya pada saat kejadian bencana.

Dengan itu, Penelitian ini bertujuan untuk mengetahui parameter lokal, lokasi serta fenomena-fenomena yang menyebabkan terjadinya hujan lebat dan banjir di Sungailiat, Kabupaten Bangka pada tanggal 12 Februari 2017. Penelitian mengenai fenomena cuaca ekstrem sebelumnya telah dilakukan diantaranya Ismail dan Siadari (2017), Kadarsah dkk (2015), Rohmawati dkk (2015), dan Fadholi dkk (2014).

\section{METODE PENELITIAN}

\subsection{Data}

Data yang digunakan dalam penelitian ini ialah data satelit Himawari-8 kanal Infrared Enhanced (IR) tanggal 12 Februari 2017 yang diperoleh ftp://satelit.bmkg.go.id, serta data pengamatan udara atas radiosonde yang diperoleh dari Stasiun Meteorologi Pangkal Pinang.

\subsection{Lokasi Penelitian}

Penelitian ini mengambil lokasi di Sungailiat, kabupaten Bangka yang terletak di $1^{\circ} 52^{\prime} 43.14 "$ LS dan $106^{\circ} 6^{\prime} 57.29 "$ BT. 


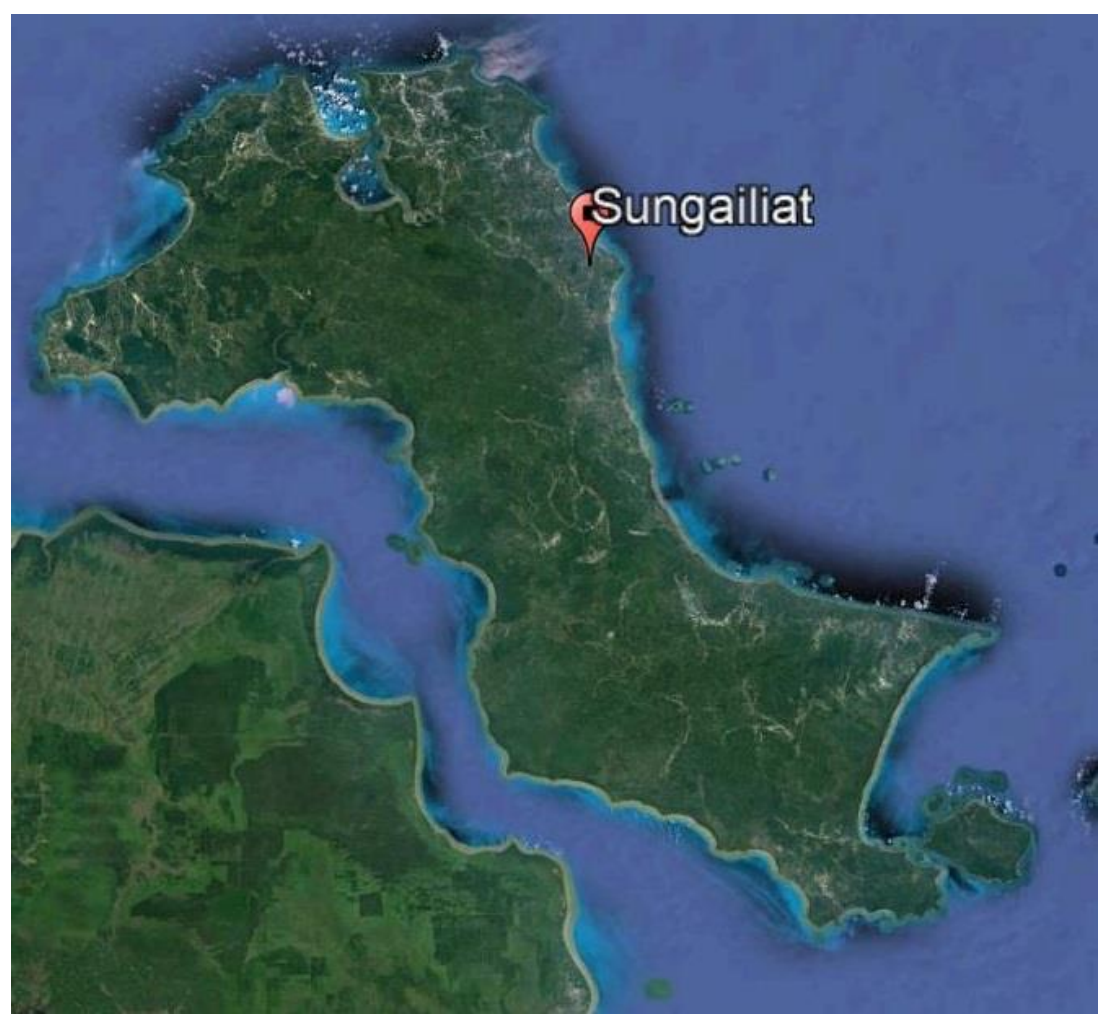

Gambar 2. Lokasi Penelitian

\subsection{Metode Penelitian}

Data - data yang telah diperoleh kemudian dikumpulkan untuk diolah menggunakan perangkat lunak (Software) yang telah tersedia. Pengolahan data citra satelit Himawari-8 kanal IR pada jam 22.00 UTC sampai 23.50 UTC yang diketahui merupakan puncak terjadinya hujan lebat untuk mengestimasi suhu puncak awan yang diturunkan dari citrasatelit Kanal I2 dengan bantuan perangkat Lunak SATAID. Secara umum aplikasi SATAID menginput data ke memory dan ditampilkan dalam bentuk peta secara spasial ataupun berupa grafik deret waktu dilakukan kemudian dianalisis untuk mengetahui kondisi atmosfer pada saat waktu kejadian hujan lebat. Pengolahan data radiosonde udara atas dengan menggunakan RAOB dianalisis untuk menentukan indeks labilitas atmosfer yang berpengaruh dalam pembentukan awan konvektif penyebab hujan lebat.

\section{HASIL DAN PEMBAHASAN}

\subsection{Analisis Atmosfer dengan Citra Satelit Himawari-8}

Untuk mendapatkan data suhu puncak awan maka dilakukan analisis citra satelit Himawari 8. Kanal yang dipilih adalah kanal I2 Melalui kanal tersebut, penulis melakukan overlay awan dan melihat pertumbuhan awan Cumulonimbus $(\mathrm{Cb})$ dan besar pengaruh awan $\mathrm{Cb}$ terhadap hujan yang terjadi di Sungailiat. Data yang didapatkan dari overlay awan adalah pertumbuhan awan $\mathrm{Cb}$ mulai terjadi diatas pukul 20.00 UTC atau 03.00 WIB, sejumlah awan yang memenuhi kriteria awan $\mathrm{Cb}$, terus tumbuh dan mencapai puncaknya pada jam 22.50 UTC kemudian perlahan-lahan mulai musnah. Berdasarkan hasil pengamatan pada saat kejadian suhu puncak awan mengalami penurunan yang cukup signifikan dimana suhu dapat mencapai 
antara $-40^{\circ} \mathrm{C}$ dan $-75^{\circ} \mathrm{C}$. Hal ini mengindikasikan terbentuknya awan-awan konvektif terutama awan $\mathrm{Cb}$ yang menjadi factor utama adanya hujan lebat yang mengakibatkan banjir di sungailiat.

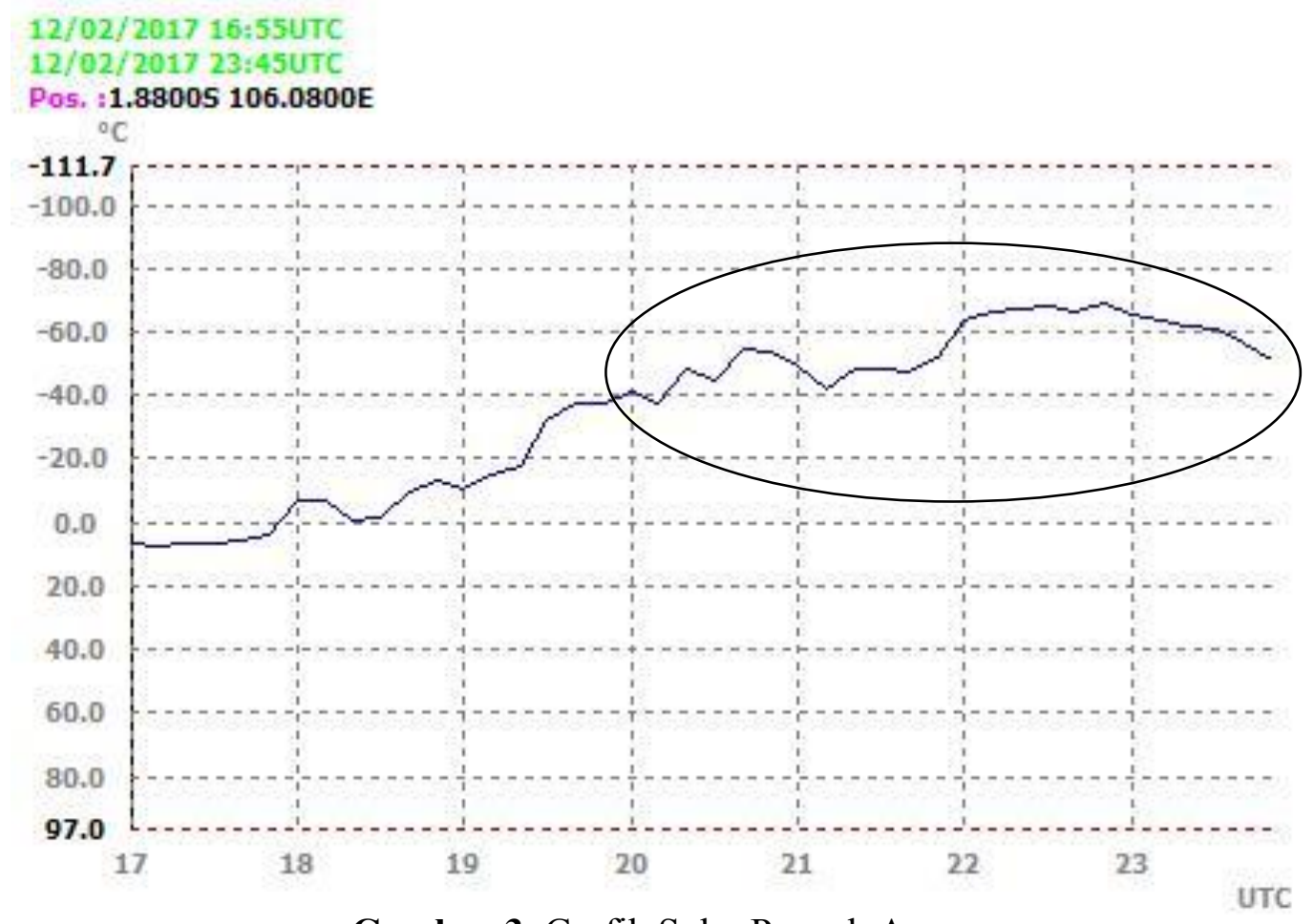

Gambar 3. Grafik Suhu Puncak Awan

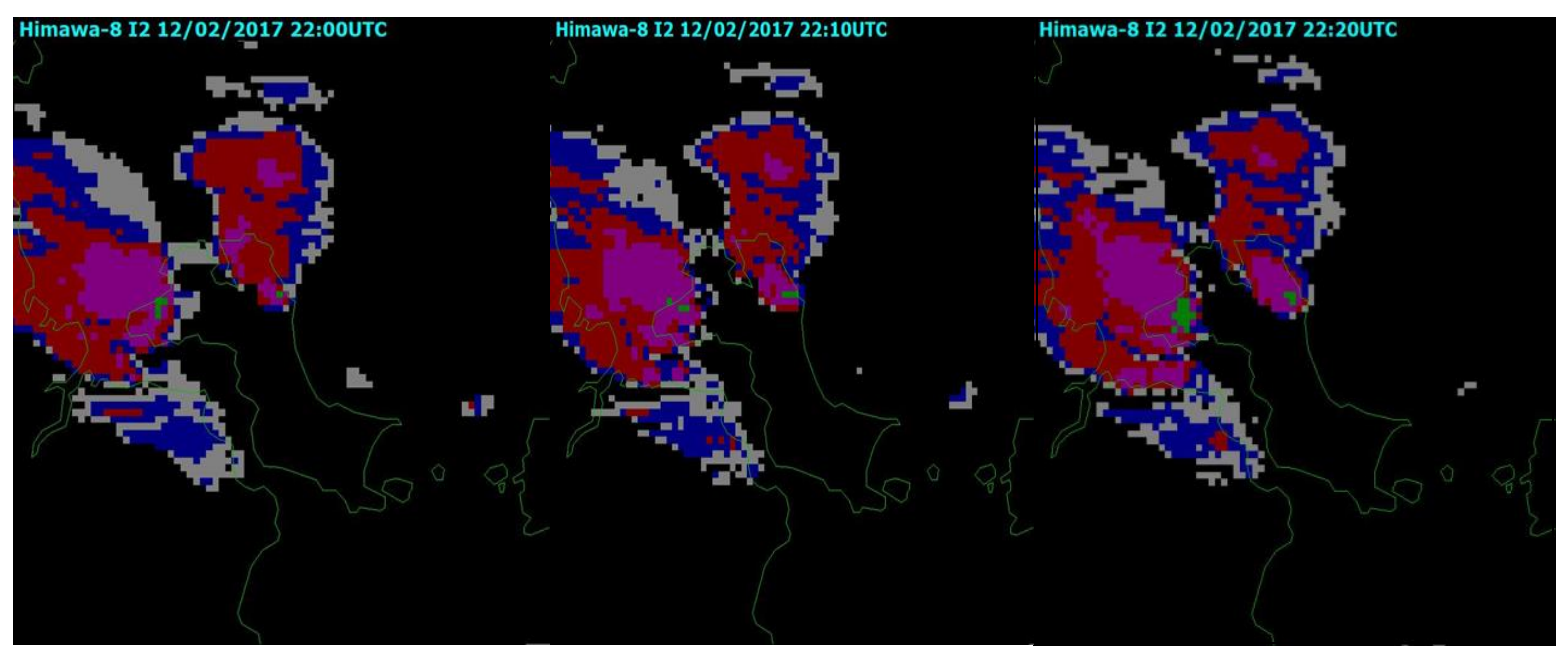




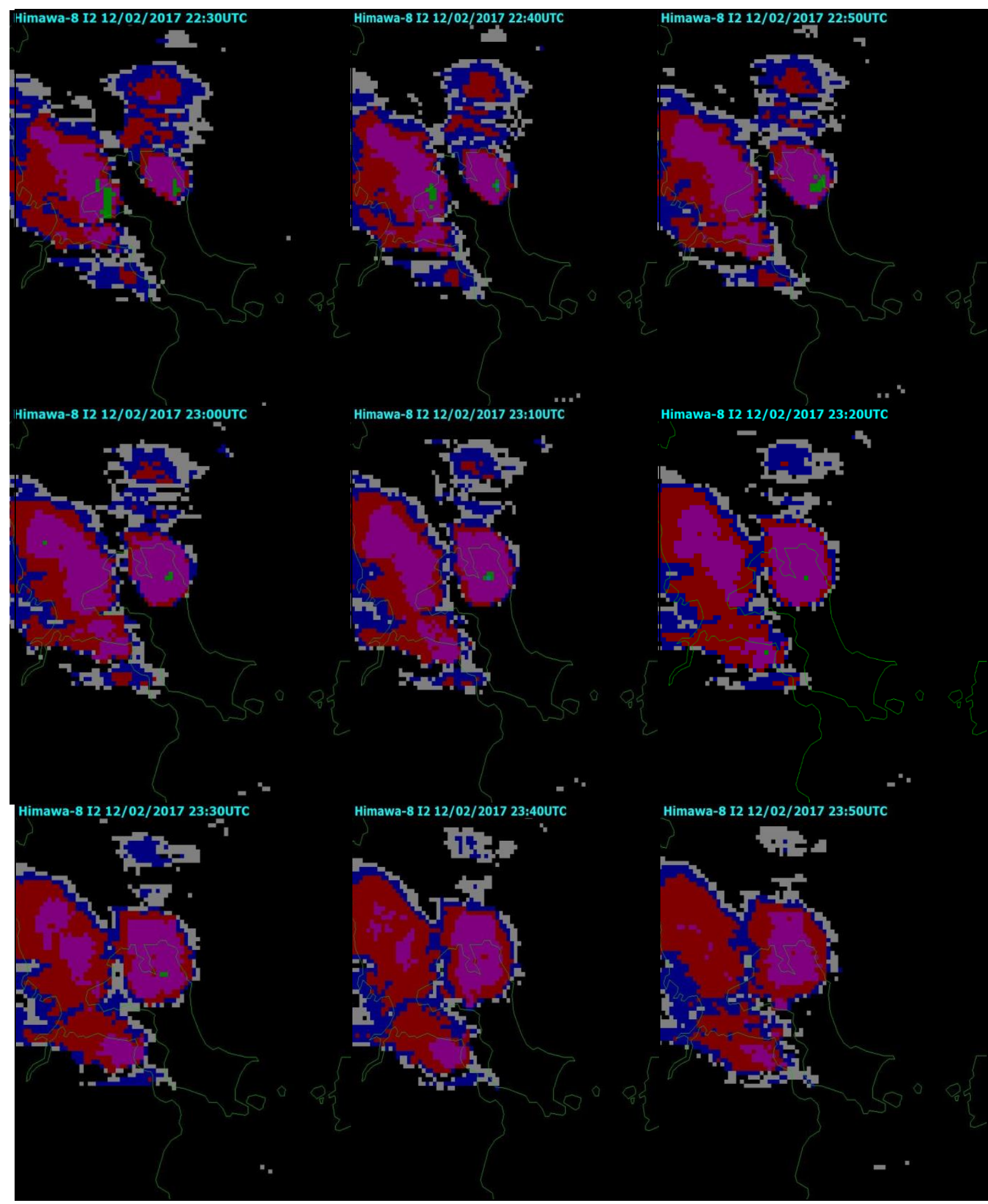

Gambar 4. Citra Satelit Himawari-8 jam 22.00 UTC sampai dengan 23.50 UTC

Berdasarkan laporan observasi yang dilakukan oleh Stasiun Meteorologi Pangkalpinang dapat diketahui bahwa curah hujan terbanyak terjadi antara jam 22.00 UTC hingga jam 23.50 UTC dimana pada jam tersebut dapat diidentifikasi adanya perawanan konvektif berupa awan $\mathrm{Cb}$. Selain itu perawanan yang terbentuk pada jam tersebut adalah awan menengah berupa As tebal dan awan tinggi Cirrus tebal. Berdasarkan data sinoptik, hujan intensitas tinggi terusmenerus berlangsung pada tanggal 12 Februari jam 20.00 UTC hingga tanggal 13 Februari 
jam 02.00 UTC dengan kondisi cuaca masih terjadi hujan intensitas ringan hingga sedang. Sehingga, hujan tersebut pada umumnya berasal dari awan konvektif terutama Cumulonimbus akibat terbentuknya shearline diatas atmosfer Sungailiat.

\subsection{Analisis atmosfer dengan Radiosonde udara atas}

Berdasarkan data pengamatan radiosonde yang dilakukan oleh Stasiun Meteorologi Pangkalpinang pada tanggal 12 Februari 2017 jam 12.00 UTC,dan tanggal 13 Februari 00.00 UTC diperoleh data seperti pada Tabel 1.

Dari data tersebut, dapat kita ketahui bahwa terdapat peningkatan aktivitas konvektif pada tanggal 12 Februari dari jam 12.00 UTC hingga jam 23.50 UTC, hal tersebut dapat diketahui dari peningkatan nilai aktivitas konvektif kemudian aktivitas tersebut menurun, tampak dari penurunan beberapa nilai parameter konvektif.

Dari hasil pengamatan sounding tersebut dapat diketahui bahwa pembentukan perawanan khususnya perawanan konvektif berasal dari proses mekanis yang didukung oleh kondisi stabilitas atmosfer labil dan kandungan uap air yang besar.

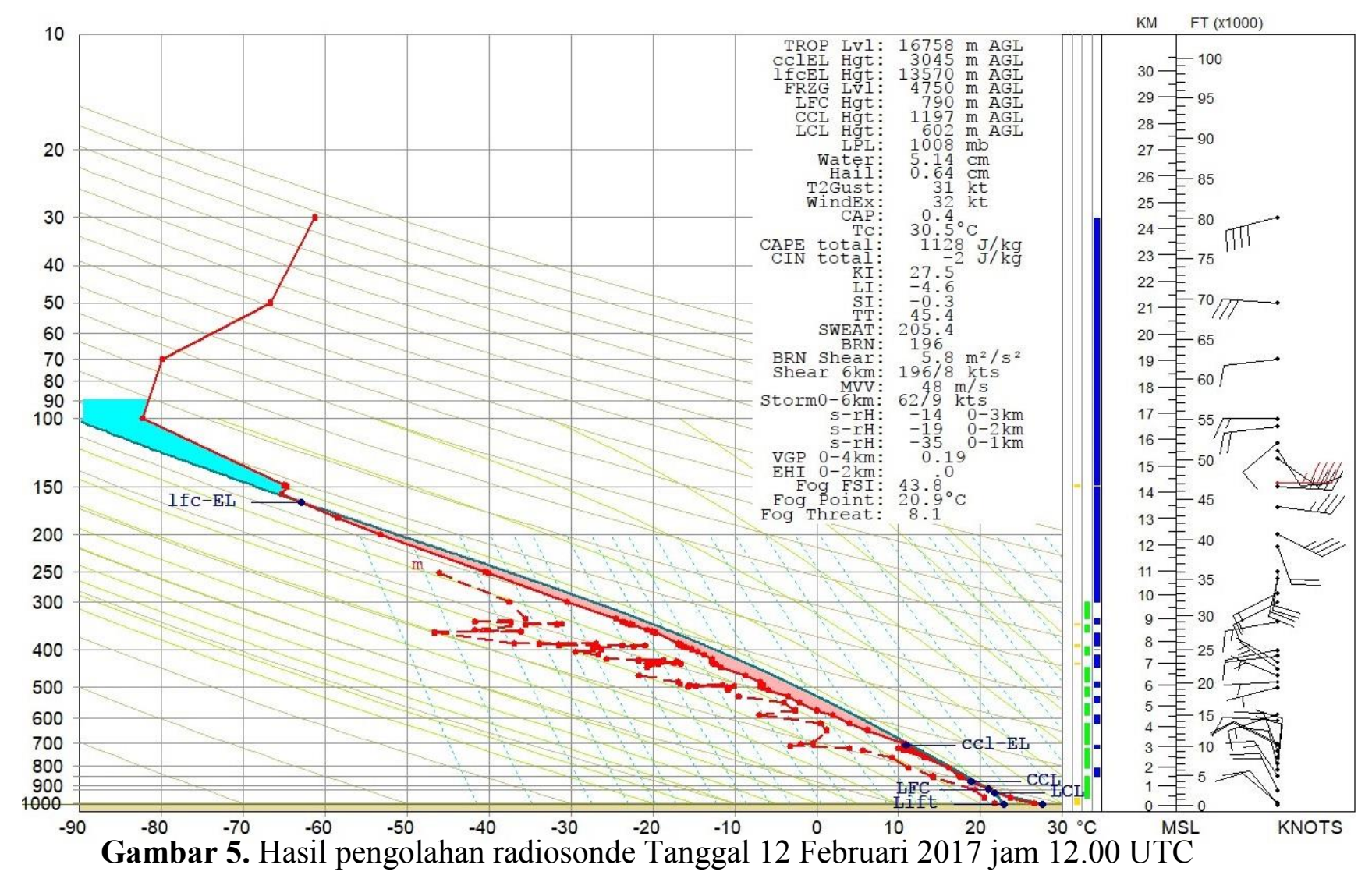


Tabel 1. Hasil Pengolahan Data Radiosonde 12 Februari jam 12.00 UTC

\section{Indeks Konvektif}

SWEAT (Severe

Weather Thread Index)

CAPE (Convective

Available Potential

Energy)

SI (Showalter Index)

LI ( Lifted Index )

TT(Total totals index)

KI ( K Index )
Jam 12.00 UTC

205.4

$1128 \mathrm{~J} / \mathrm{kg}$

$-0.3$

$-4.6$

45.4

27.5
Keterangan

Thunderstorm ringan

Ketidakstabilan sedang

Kemungkinan Thunderstorm

Labil dan Kemungkinan

Thunderstorm

Konveksi kuat dan potensi petir Konveksi sedang

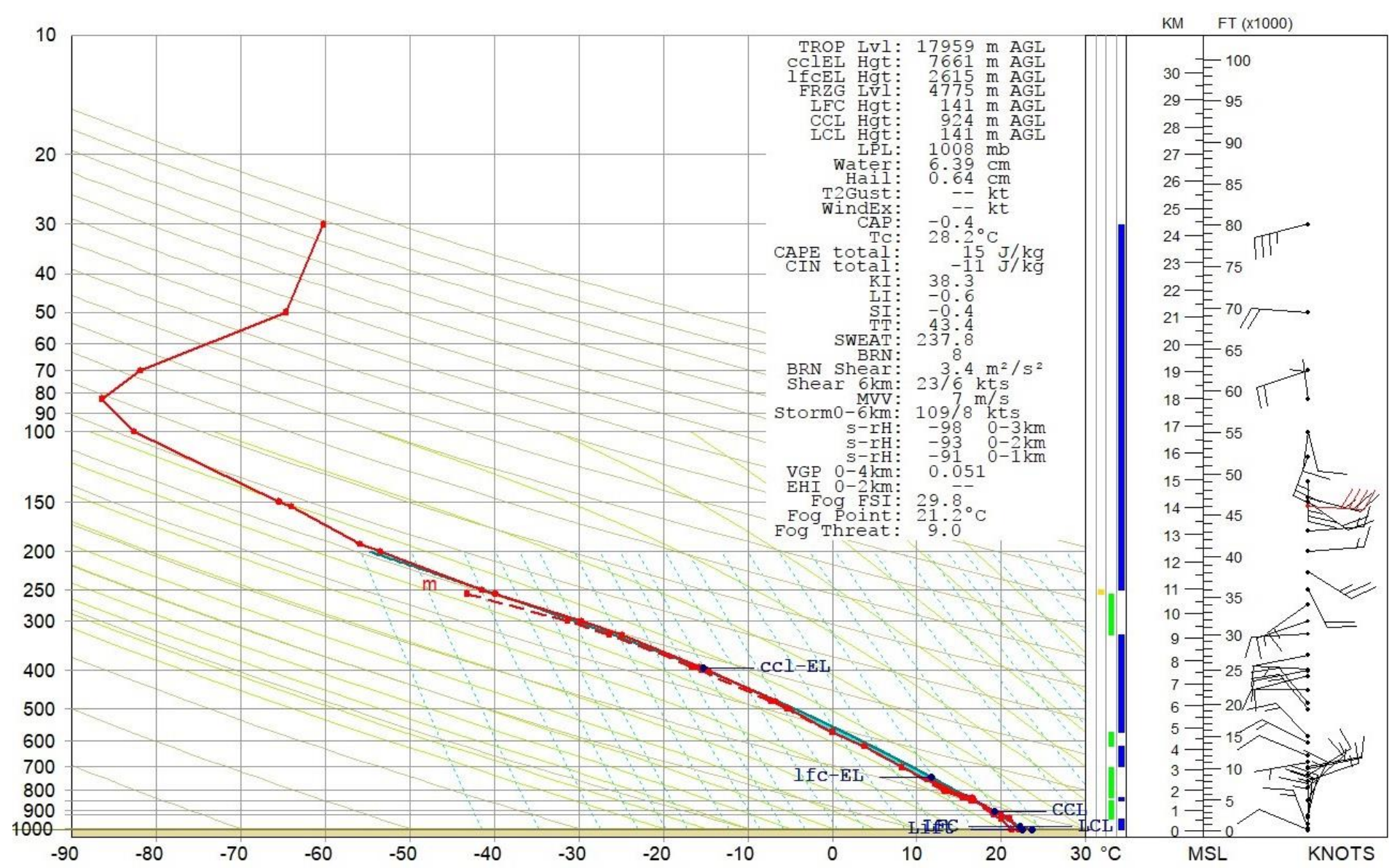

Gambar 6. Hasil pengolahan radiosonde Tanggal 13 Februari 2017 jam 00.00 UTC 
Tabel 1. Hasil Pengolahan Data Radiosonde 13 Februari jam 10.00 UTC

\begin{tabular}{lcc}
\hline \multicolumn{1}{c}{ Indeks Konvektif } & Jam 00.00 UTC & Keterangan \\
\hline SWEAT (Severe & 237.8 & Thunderstorm ringan \\
Weather Thread Index) & & \\
CAPE (Convective & $15 \mathrm{~J} / \mathrm{kg}$ & Ketidakstabilan lemah \\
Available Potential & & \\
Energy) & -0.4 & Kemungkinan Thunderstorm \\
SI (Showalter Index) & -0.6 & Agak tidak stabil \\
LI ( Lifted Index ) & 43.4 & Konveksi lemah \\
TT(Total totals index) & 38.3 & Konveksi sedang \\
KI ( K Index ) & & \\
&
\end{tabular}

Melalui indeks hasil pengamatan dapat diketahui bahwa pada pengamatan malam 12 februari jam 12.00 UTC nilai Showalter Index (SI) 205.4, nilai Lifted Index (LI) -4.6, nilai Total-totals Index (TT) 45.40, Convective Available Potential Energy Index (CAPE) 1128 $\mathrm{J} / \mathrm{Kg}$, dan Nilai K Index(KI) 32,90. Sedangkan pada pengamatan pagi hari, 13 februari jam 00.00 UTC nilai Showalter Index (SI) -0.4, nilai Lifted Index (LI) -0.6, nilai Total-totals Index (TT) 43.4, Convective Available Potential Energy Index (CAPE) $15 \mathrm{~J} / \mathrm{Kg}$,dan Nilai K Index (KI) 38.3. Dari nilai indeks tersebut dapat disimpulkan bahwa kondisi atmosfer saat malam hari sangat labil,dengan adanya tambahan gaya/energi yang mengakibatkan terjadi gangguan atmosfer di sekitar wilayah Tersebut. Saat pagi hari, teramati kondisi atmosfer stabil akibat telah melepaskan energi yang kuat di waktu sebelumnya.

\section{KESIMPULAN}

Dari berbagai analisis yang telah dilakukan terhadap kondisi atmosfer sungailiat, kabupaten Bangka terkait fenomena hujan lebat yang mengakibatkan banjir pada tanggal 12 Februari 2017, yang dianalisis secara lokal dapat disimpulkan bahwa :

1. Dari analisis data satelit dapat diketahui bahwa perawanan yang terbentuk pada tanggal 12 Februari 2017 didominasi awan konvektif Cumulonimbus $(\mathrm{Cb})$ hal ini dapat dilihat dari suhu puncak awan mencapai $-75^{\circ} \mathrm{C}$ pada pukul $22.50 \mathrm{WIB}$

2. Hasil Radiosonde udara atas sebelum terjadinya fenomena hujan lebat yaitu pada pukul 12.00 UTC menunjukkan kondisi atmosfer labil, sehingga mendukung terbentuknya awan konvektif atau thunderstorm.

\section{SARAN}

Perlu dikembangkan lagi terkait metode penelitian yang menganalisis faktor penyebab cuaca global, regional dan lokal.

\section{DAFTAR PUSTAKA}

Kadarsah, A. Sasmito, E. E. Syahputra, T. A. Nuraini, dan E. Aldrian, (2015). Kajian Curah Hujan Tinggi 9-10 Februari 2015 di DKI Jakarta. Jakarta: Pusat Penelitian dan Pengembangan BMKG

Fadholi, A. (2015). Kajian Meteorologi Terkait Hujan Lebat di Pulau Bangka Tanggal 28-29 Desember 2013. Megasains. Vol 6. No 2

Sub Bidang Informasi Meteorologi (BMKG). (2013). Buku Paket Pelatihan Kualifikasi Cuaca 
Penerbangan Pelatihan

Zakir, A., Khotimah, M. K., Sulistya, W. (2009). Perspektif Operasional Cuaca Tropis. Jakarta: Puslitbang BMKG

Widiatmoko, H.,dan Siswadi. (2005). Metode Analisis dan Peramalan Cuaca Jangka Pendek Mempergunakan Diagram

Aerologi Skew T, Log P. Jakarta: Deputi Bidang Sistem Data dan Informasi BMKG

Zakir, A. Sulistya, W. Khotimah, M. K. (2010). Perspektif Operasional Cuaca Tropis. Buletin Meteorologi, Klimatologi, dan Geofisika. Jakarta: BMKG

Winarso, P A. (2009). Analisa Cuaca II. Jakarta: Akademi Meteorologi dan Geofisika

Zakir, A. (2010). Modul Diklat Meteorologi Publik. Jakarta: Pusat Pendidikan dan Pelatihan BMKG

Maulani, Q. 2014. Kajian Meteorologi Terkait Hujan Lebat Menggunakan Satelit TRMM, Satelit MT-SAT, dan Data Reanalisis. Skripsi Program Sarjana Terapan Meteorologi. Sekolah Tinggi Meteorologi Klimatologi dan Geofisika, Jakarta.

Prakoso, A., Kristianto, A. 2015. Kajian Gangguan Cuaca Pada Kejadian Hujan Lebat di Batam (Studi Kasus Tanggal 19 Desember 2014). Skripsi Program Sarjana Terapan Meteorologi. Sekolah Tinggi Meteorologi Klimatologi dan Geofisika, Jakarta. 